\title{
CIRCULATORY DYNAMICS IN THE BASAL STATE OBSERVED DURING CONVALESCENCE. CHANGES IN BODY WEIGHT, BLOOD VOLUME, AND VENOUS PRESSURE ${ }^{1,2}$
}

\author{
By GEORGE R. MENEELY, ALBERT SEGALOFF, AND E. B. WELLS \\ (From the Department of Medicine of Vanderbilt University School of Medicine, \\ Nashville, Tennessee)
}

(Received for publication May 24, 1946)

Complaints of the circulatory symptoms of palpitation, tachycardia out of proportion to exertion, postural vertigo, and dyspnea are frequent among convalescents as a group. The present study was undertaken to determine if the commonly employed methods of evaluating circulation could be used in the prognostic classification of convalescents, and if such methods would indicate underlying physiological disturbances susceptible to modification with an ultimate shortening of the recovery period.

\section{MATERIAL AND PROCEDURES}

The 20 male subjects studied were civilians of military age who had had acute infectious diseases or surgical operations from which recovery was' expected within a reasonable period of time. The purpose and general nature of the procedures were explained to the patients who volunteered to cooperate, although some were not too enthusiastic. Studies were begun within a few days of the subsidence of obvious manifestations of illness, such as tachycardia and fever, and at the time when clinical judgment indicated that convalescence had indeed begun. A number of these patients returned for follow up study upon regaining their usual good health. Fourteen of these follow up studies were satisfactory.

Difficulties were encountered in choosing and setting up a series of tests of circulatory function in convalescents. The earlier procedures, requiring several hours for completion, were too rigorous as evidenced by manifestations of severe malaise, nausea, vomiting, diarrhea, or headache. Patients complained bitterly upon their return to the ward and vowed not to participate further in the studies. However, as these individuals had no fever or clinical signs of toxic reaction to the chemicals employed in various tech-

1 The work described in this paper was done under a contract, recommended by the Committee on Medical Research, between the Office of Scientific Research and Development and Vanderbilt University.

2 This work was done in the Lung Station of the Department of Medicine, a laboratory organized under a grant from the Commonwealth Fund, and some of the equipment used was available through a grant by the Ciba Pharmaceutical Products, Inc. nics, the same materials were used in subsequent and less rigorous schedules of tests. When the procedures were too long or caused discomfort the patients became restless and uncooperative before the end of the period of observation.

Since such stress did not seem advisable in early convalescence, and the results were invalidated by it, the schedule was modified to levels of exertion well tolerated by the patients who then remained cooperative throughout the period of study. The earlier results, obtained when the patients reacted unfavorably during or following the series of tests, were discarded because we are skeptical of the value of such tests under any but basal conditions or those of accurately measured and reproducible stress. Changes in circulation resulting from the rigors of the earlier studies were not further investigated.

The series of observations finally adopted for use required about 11/2 hours to complete and included ballistocardiographic records, pulse and respiratory rate, arterial blood pressure, oxygen consumption, blood volume, venous pressure, hematocrit, circulation time, weight, height, electrocardiogram, and a teleroentgengram of the chest.

The general nature of the procedure was explained to the patient, who cooperated purely upon a volunteer basis. Instructions were given to keep the patient in bed on the morning of the test, not to disturb him for routine care, and to delay the morning meal. He was brought to the laboratory upon a rolling stretcher, usually about $6: 30$ or 7:00 A.M. Here he was transferred to the ballistocardiograph bed (1) and allowed to rest undisturbed for $1 / 2$. hour. The ballistocardiographic deflections were then photographed. Following this, the pulse and respiration rate were recorded and the arterial blood pressure determined with a mercurial manometer. Then, by using a Benedict-Roth closed breathing circuit, a respiratory tracing over a 7-minute period was obtained in duplicate. - The blood volume was estimated by the method of Gibson and Evans (2). Four samples of blood were delivered into Gibson tubes containing 20 volumes per cent of isotonic potassium oxalate for hematocrit values. Samples of serum were reserved for determination of total protein by the copper sulphate specific gravity method (3). During the blood volume determination, the venous pressure was measured directly with a saline manometer referred to a point $6 \mathrm{~cm}$. below the angle of Louis with the patient supine (4). After completion of the blood volume determination, the blood velocity was 
measured using Macasol ${ }^{3}$ by the method of Spier, Wright, and Saylor (5). An electrocardiogram was taken. The patient was then weighed, measured, and transferred by roller stretcher to the X-ray room where a 6-foot film was obtained with the patient erect, either sitting or standing.

The ballistocardiograph employed in this study has been described elsewhere (6) and had physical properties essentially identical with the instrument of Starr and associates (1). The cardiac output was calculated by the area formula (1), modified slightly for the method of standardization employed by the authors. The cardiac output per minute per pound of body weight was compared with Starr's normal standard (7). Starr's normal data were recalculated in terms of cardiac output per calory of predicted basal metabolic rate, with slight improvement in deviations for sex and age, and our findings compared with their recalculated standards.

Heat production was calculated in the usual way from oxygen consumption and compared with predicted values from the Aub-DuBois standard (8). The difference was expressed as a percentage of normal as the usual basal metabolic rate.

Ventilation per minute was determined by integrating the respiratory tracing, and the utilization coefficient of Herbst (9) was derived from this and from the oxygen consumption, expressed as milliliters of oxygen consumed per liter ventilated.

Plasma volumes were calculated from curves of blue dye disappearance, and the total blood volume and cell volume were derived by the use of the hematocrit ratio from antecubital venous blood. Blood volumes were compared with the standards of Gibson and Evans (10) basing the prediction upon the height of the patient.

The transverse diameter of the heart was measured in the teleroentgengram as was the internal diameter of the chest at the level of the fourth costochondral junction. In our experience this latter measure is less subject to irrelevant variation than the usual measure made at a lower level in the rib skirt. The ratio of the heart diameter to the internal diameter of the chest was then calculated.

\section{RESULTS}

Data from various tests are given in Table I, including the mean values and standard deviations of the observations made during early convalescence, and the mean differences between these initial values and those following recovery. The mean values of the initial studies do not deviate from commonly accepted normal standards, with the exception of blood velocity. Whether this latter difference is real is discussed below.

There was no uniformity in the changes in systolic and diastolic blood pressure or in the pulse

${ }^{3}$ Supplied through the courtesy of the Nepera Chemical Co., Yonkers, New York.
TABLE I

Mean values of observations of convalescent male civilians of military age and the mean difference upon recovery

\begin{tabular}{|c|c|c|c|c|}
\hline & $\begin{array}{l}\text { No. } \\
\text { of } \\
\text { cases }\end{array}$ & $\begin{array}{l}\text { Initial } \\
\text { mean and } \\
\text { standard } \\
\text { deviation }\end{array}$ & $\begin{array}{c}\text { No. } \\
\text { of } \\
\text { cases }\end{array}$ & $\begin{array}{l}\text { Mean } \\
\text { differ- } \\
\text { ence } \\
\text { upon } \\
\text { recovery }\end{array}$ \\
\hline $\begin{array}{l}\text { Weight, kgm. } \\
\text { Respiratory rate per min. } \\
\text { Blood pressure, mm. Hg }\end{array}$ & $\begin{array}{l}20 \\
19\end{array}$ & $\begin{array}{l}62.25 \pm 9.80 \\
16.50 \pm 2.80\end{array}$ & $\begin{array}{l}14 \\
13\end{array}$ & $\begin{array}{l}+3.60 * \\
-1.80\end{array}$ \\
\hline $\begin{array}{l}\text { Systolic } \\
\text { Diastolic } \\
\text { Av. systolic and diastolic } \\
\text { Venous pressure, mm. saline }\end{array}$ & $\begin{array}{l}20 \\
20 \\
20 \\
20\end{array}$ & $\begin{array}{r}112.80 \pm 7.80 \\
70.40 \pm 9.90 \\
91.60 \pm 9.30 \\
71.60 \pm 26.10\end{array}$ & $\begin{array}{l}14 \\
14 \\
14 \\
14\end{array}$ & $\begin{array}{l}+5.80 \\
+0.60 \\
+3.20 \\
+24.60 *\end{array}$ \\
\hline $\begin{array}{l}\text { Circulation time, sec. } \\
\text { Arm to tongue } \\
\text { Arm to hand } \\
\text { Arm to perineum } \\
\text { Arm to foot }\end{array}$ & $\begin{array}{l}20 \\
19 \\
19 \\
11\end{array}$ & $\begin{array}{l}19.10 \pm 4.20 \\
27.90 \pm 7.10 \\
30.10 \pm 9.20 \\
39.50 \pm 11.70\end{array}$ & $\begin{array}{l}12 \\
12 \\
10\end{array}$ & $\begin{array}{l}=0.40 \\
-0.30 \\
-0.70\end{array}$ \\
\hline \multirow{3}{*}{$\begin{array}{l}\text { Cardiac output } \\
\text { Per stroke, ml. } \\
\text { Per min., liters } \\
\text { Per lb. per min., ml. } \\
\text { Per min. per cal. predicted } \\
\text { B.M.R., ml. } \\
\text { Per min. per cal. observed } \\
\text { B.M.R., ml. }\end{array}$} & & & & \\
\hline & $\begin{array}{l}17 \\
17 \\
17 \\
17\end{array}$ & $\begin{array}{r}48.60 \pm 11.30 \\
3.41 \pm 0.57 \\
24.20 \pm 4.40 \\
47.60 \pm 8.40\end{array}$ & $\begin{array}{l}9 \\
9 \\
9 \\
9\end{array}$ & $\begin{array}{l}-0.80 \\
-0.29 \\
-3.50 \\
-5.10\end{array}$ \\
\hline & 13 & $48.40 \pm 7.10$ & 7 & -0.20 \\
\hline $\begin{array}{l}\text { B.M.R., per cent } \\
\text { Utilization coefficient } \\
\text { Ventilation, liters } \\
\text { Tidal air, ml. } \\
\text { Heart size, transverse } \\
\text { diameter, cm. }\end{array}$ & $\begin{array}{l}17 \\
17 \\
17 \\
17 \\
19\end{array}$ & $\mid \begin{array}{c}-2.90 \pm 9.50 \\
39.30 \pm 7.60 \\
5.90 \pm 0.90 \\
443.00 \pm 123.00 \\
12.40 \pm 1.30\end{array}$ & $\begin{array}{r}10 \\
9 \\
9 \\
9 \\
12\end{array}$ & $\begin{array}{r}-3.10 \\
+0.30 \\
+0.10 \\
+21.20 \\
+0.40\end{array}$ \\
\hline $\begin{array}{l}\text { Hematocrit value, vol. per cent } \\
\text { Blood volume, liters } \\
\text { Plasma volume, liters } \\
\text { Cell volume, liters } \\
\text { Plasma total protein, grams } \\
\quad \text { per cent }\end{array}$ & $\begin{array}{l}20 \\
20 \\
20 \\
20 \\
19\end{array}$ & $\begin{array}{r}43.60 \pm 5.60 \\
5.35 \pm 0.63 \\
2.98 \pm 0.32 \\
2.37 \pm 0.49 \\
6.70 \pm 0.60\end{array}$ & $\begin{array}{l}14 \\
13 \\
13 \\
13 \\
12\end{array}$ & $\begin{array}{l}+1.70 \\
+0.46^{*} \\
+0.19 * \\
+0.28 * \\
+0.20\end{array}$ \\
\hline Circulating plasma total protein & 19 & $199.10 \pm 26.00$ & 12 & +10.20 \\
\hline
\end{tabular}

* Changes considered significant.

pressure recorded in early convalescence and recovery, since about half of the group showed an increase, the remainder a decrease in pressure.

From Table I, it is apparent that the blood velocity was the same in convalescence and health. The data from arm-to-foot determinations following recovery were too few to be included.

The values for the mean cardiac output per minute per pound of body weight in convalescence compare favorably with Starr's (7) figure of 23 ml. per minute per pound as the normal mean. The mean decrease of $3.5 \mathrm{ml}$. per minute per pound after recovery was due to the increase in body weight rather than to the small decrease in minute volume.

A correlation of the cardiac output per minute with the predicted and observed basal metabolic rate in the recovery and convalescent states was fruitless. Recalculation of Starr's data for normal subjects showed the mean normal value for cardiac output per minute per calory of the predicted B.M.R. to be $50 \mathrm{ml}$., with a range of 40 to $60 \mathrm{ml}$,, 
corresponding to Starr's range of 18-29 ml. per minute per pound of body weight.

From the data obtained in these studies it cannot be said that the basal metabolic rate is useful as a criterion for convalescence. In central Tennessee, where all of these studies were made, general experience indicates that a mean basal value of minus 5 per cent by the Aub-DuBois standard may be regarded as normal; farther south, in New Orleans, the figure is minus 10 per cent (11).

As might be inferred from the data on ventilation and the basal metabolic rate, the relation between ventilation and the oxygen consumption expressed by Herbst's coefficient (9) was neither abnormal initially nor was it significantly altered subsequently. The mean coefficient was $39.3 \pm$

\% oeviation observed ouring convalescence REFERRED TO RECOVERY VALUE AS zERO

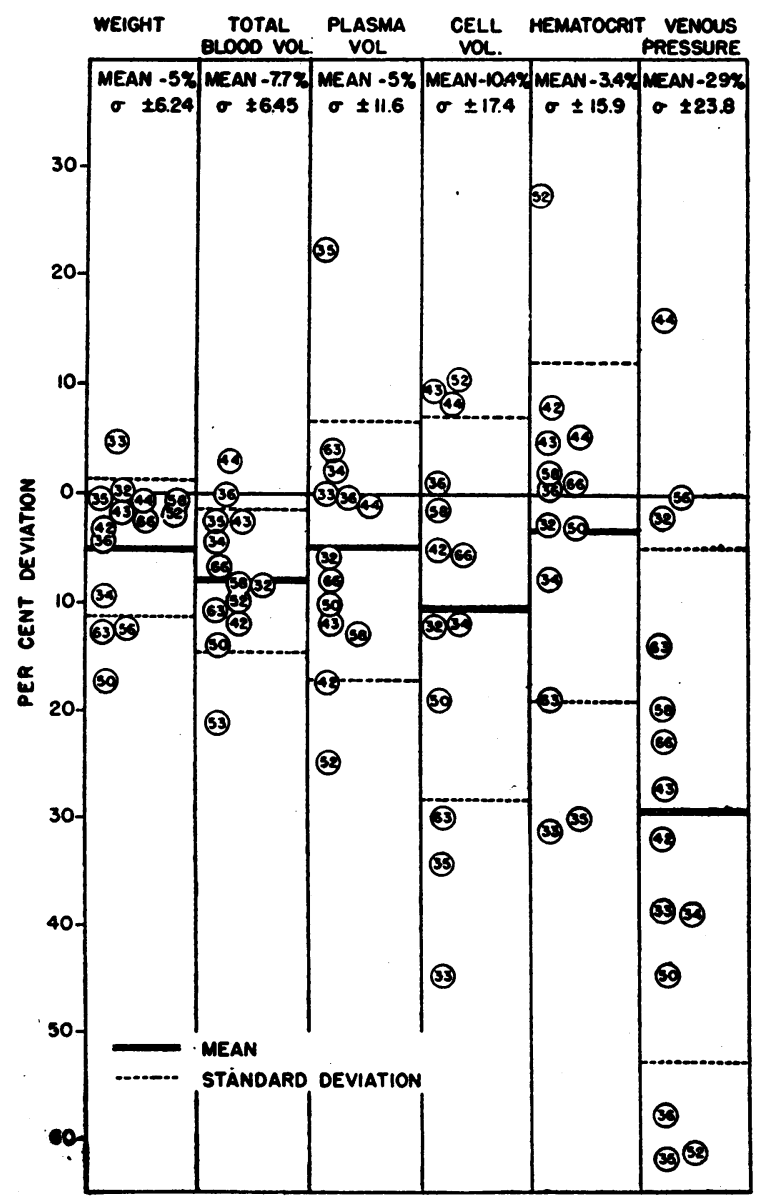

Figure 1.
TABLE II

Blood volume studies, blue dye method, of adult males

\begin{tabular}{l|c|c|c}
\hline \hline & $\begin{array}{c}\text { No. } \\
\text { of } \\
\text { cases }\end{array}$ & $\begin{array}{c}\text { Initial } \\
\text { observa- } \\
\text { tions: } \\
\text { mean }\end{array}$ & $\begin{array}{c}\text { Mean } \\
\text { difference } \\
\text { 1st and } \\
\text { 2nd obs. }\end{array}$ \\
\hline $\begin{array}{l}\text { House officers, normal males (13) } \\
\text { Convalescents } \\
\text { Gibson's normal males (10) }\end{array}$ & $\begin{aligned} 5 \\
\text { 20 }\end{aligned}$ & $\begin{array}{l}5.57 \text { liters } \\
59.35 \text { liters }\end{array}$ & $\begin{array}{l}\mathbf{5 . 3 4} \text { liters } \\
\text { t0.461 liter* }\end{array}$ \\
\hline
\end{tabular}

* This represents the mean increase after recovery in the case available for a second observation.

The data on the 5 house officers studied on 2 occasions months apart are included to show that there is little deviation attributable to the method in the study of a group. The mean difference of 0.461 liter between the blood volumes observed in convalescence and in the same cases after recovery is contrasted to the lack of difference in the 5 normal males restudied.

$7.6 \mathrm{ml}$. of oxygen consumed per liter ventilated. After recovery there was a mean increase of 0.31 ml. The normal mean obtained by Hurtado and Boller (12) who used the same procedure was $37.5 \mathrm{ml}$. oxygen per liter ventilated, with a coefficient of variation of \pm 27 per cent. The mean increase of $0.37 \mathrm{~cm}$. in the transverse diameter of the heart cannot be regarded as significant.

From the data it was obvious that weight differences between a patient's reported normal and his observed weight in early convalescence could not be relied upon as a criterion of convalescence. This is illustrated by a discrepancy between the weight loss reported and the weight regained by the individuals followed to recovery. While the patients appeared to have lost an average of 6.11 kgm., to judge from the difference between the patient's estimate of his usual weight and his actual weight during convalescence, yet.upon return to usual health, the weight regained averaged only $3.59 \mathrm{kgm}$. (Table I and Figure 1).

Table II contains data on blood volume obtained from: (a) 5 house officers among whom there was no reason to consider a physical or medical change in status during the 6-month interval elapsing between the 2 determinations (13), (b) our convalescent and recovered groups or subjects, and (c) Gibson's mean of blood volumes in 49 normal males (10). The blue dye method of Gibson (2) was used in all of these studies. Many of the normal values included in Gibson's study were obtained from hospital-bed patients, which might explain the difference between his average total blood volume in males, 5.35 liters, and the aver- 
age blood volume, 5.76 liters, in our group of recovered ambulatory subjects.

The increase in total volume of the blood was due to both plasma and cell increases, the latter change predominating in patients frankly anemic in the early convalescent state, the former in those with high hematocrit values in convalescence (Table I and Figure 1).

The venous pressure was significantly increased after recovery in most subjects; it was unchanged in one, and decreased $8 \mathrm{~mm}$. saline in another, the mean increase being $24.6 \mathrm{~mm}$. saline, the greatest, $73 \mathrm{~mm}$. saline, representing a mean increase of 35 per cent (Figure 1 and Table I).

The electrocardiograms were within normal limits in convalescents and following recovery there was no significant change. Plasma total protein and circulating plasma total protein showed no significant change.

\section{DISCUSSION}

It is at once evident that the circulation at rest during early convalescence deviates only slightly from normal. The 2 particulars in which deviations were found were blood volume and venous pressure. To these might be added body weight, for some part of the weight deficit appears to be interstitial water (14).

The deficit in blood volume is of the same order of magnitude as that found by Keys and his associates (15) and by Barr and his associates (16) in normal men at bed rest, and by Rutstein (14) in convalescence from pneumonia. Loss of about $1 / 2 \mathrm{kgm}$. of body weight and about 100 grams of protein may be accounted for by the observed deficit in blood volume.

The question arises as to whether these blood volume changes are real. Cruickshank's (17) reiteration of Smith's (18) observation that some unknown fraction of the administered dye is taken up by the reticulo-endothelial system immediately is a valid criticism of the method. The discrepancy between venous and general body hematocrit values (19) is another. Although there is no evidence that errors in the blood volume are consistent on different occasions when the patient is in different clinical states, yet it is to be hoped this is the case so that changes observed in a patient from time to time may be real even though the absolute values are incorrect. The reproducibility of results obtained by the method of Gibson and Evans (2) may be seen in the normal house officers (Table II) who were studied at different times of the year.

The rise in venous pressure upon recovery is not explained. It was not related to changes in cardiac output, to blood volume, nor to any other measurement we made.

It is interesting to compare our findings with those of Lyons and his associates (20) who have recently reported extremely interesting observations on normal individuals who underwent diuresis with ammonium chloride and mercupurin. There was a loss in body weight of a little over $3 \mathrm{r} / 2 \mathrm{kgm}$. associated with a fall in plasma volume slightly, over $700 \mathrm{ml}$. Much of the diminution in body weight was aparently due to diminution of interstitial water. His subjects exhibited symptoms "suggestive of an inadequate circulation . . . they complained of weakness, prostration, fatigue, and some felt so faint attempting to stand that they chose to remain in bed." The striking similarity of these symptoms to symptoms experienced by patients during early convalescence is obvious, and possibly the mechanism of production of these manifestations is closely related in the 2 cases.

The values obtained for circulation time seemed long to us. However, as patients returned for follow up without change, we were compelled to reinvestigate the normal standards for this method in our hands. Forty-six normal men in the basal state formed the material for this review and the results are to be published elsewhere (21). Suffice it to say there was no significant difference between the blood velocity in these normals and that found in our early convalescents.

\section{SUM MARY}

1. The following measurements were made upon a group of basal convalescent male patients who had undergone infectious disease or surgical operation : height, weight, pulse, respiration, arterial and venous blood pressure, blood velocity from arm to tongue, hand, perineum and feet, cardiac output, cardio-thoracic ratio, oxygen consumption, basal metabolic rate, ventilation, tidal air, utilization coefficient, hematocrit value, total blood volume, plasma volume and cell volume, plasma 
total protein, circulating plasma total protein, and an electrocardiogram. None of these observations indicated any characteristic abnormality of the circulation when the results were compared with currently accepted normal standards; so none of these tests is of any use as a routine procedure for the clinical classification of convalescence.

2. Follow up studies revealed small but significant alterations which could be detected only by comparing the individual with himself as a control. These differences were: a deficit in body weight of $3.6 \mathrm{kgm}$., a deficit during early convalescence of approximately $1 / 2$ liter of blood volume, and a deficit of 35 per cent of the patient's usual venous pressure.

\section{BIBLIOGRAPHY}

1. Starr, I., Rawson, A. J., Schroeder, H. A., and Joseph, N. R., Studies on the estimation of cardiac output in man, and of abnormalities in cardiac function, from the heart's recoil and the blood's impacts; the ballistocardiogram. Am. J. Physiol., 1939, 127, 1.

2. Gibson, J. G., II, and Evans, W. A., Jr., Clinical studies of the blood volume. I. Clinical application of a method employing the azo dye "Evans blue" and the spectrophotometer. J. Clin. Invest., 1937, 16, 301.

3. Phillips, R. A., Van Slyke, D. D., Dole, V. P., Emerson, K., Jr., Hamilton, P. B., and Archibald, R. M., Copper sulfate method for measuring specific gravities of whole blood and plasma. The United States Navy Research Unit at the hospital of the Rockefeller Institute for Medical Research.

4. Griffith, G. C., Chamberlain, C. T., and Kitchell, J. R., A simplified apparatus for direct venous pressure determination modified from Maritz and V. Tabora. Am. J. M. Sc., 1934, 187, 371.

5. Spier, L. C., Wright, I. S., and Saylor, L., New method for determining circulation time throughout vascular system. Am. Heart J., 1936, 12, 511.

6. Meneely, George R., to be published.

7. Starr, I., and Schroeder, H. A., Ballistocardiogram. II. Normal standards, abnormalities commonly found in diseases of the heart and circulation, and their significance. J. Clin. Invest., 1940, 19, 437.

8. DuBois, E. F., Basal Metabolism in Health and Disease. Philadelphia, Lea and Febiger, 1927.

9. Herbst, R., Der Gasstoff wechsel als Mass der Körperlichen Leistungsfähigkeit. I. Die Bestimmung des Sauerstoffaufnahmevermögens beim Gesunden. Deutsches Arch. F. klin. Med., 1928, 162, 33.

10. Gibson, J. G., II, and Evans, W. A. Jr., Clinical studies of the blood volume. II. The relation of plasma and total blood volume to venous pressure, blood velocity rate; physical measurements, age, and sex in ninety normal humans. J. Clin. Invest., 1937, 16, 317.

11. Andes, J. E., and Eaton, A. G., Synopsis of Applied Pathological Chemistry. 376. St. Louis, C. V. Mosby Company, 1941.

12. Hurtado, A., and Boller, C., Studies of total pulmonary capacity and its subdivisions. I. Normal absolute and relative values. J. Clin. Invest., 1933, $12,793$.

13. Kaltreider, N. L., Meneely, G. R., Allen, J. R., and Bale, W. F., Determination of the volume of the extracellular fluid of the body with radioactive sodium. J. Exper. Med., 1941, 74, 569.

14. Rutstein, D. D., Thomson, K. J., Tolmach, D. M., Walker, W. H., and Floody, R. J., Plasma volume and "extra vascular thiocyanate space" in pneumococcus pneumonia. J. Clin. Invest., 1945, 24, 11.

15. Taylor, H. L., Erickson, L., Henschel, A., and Keys, A., The effect of bed rest on the blood volume of normal young men. Am. J. Physiol., 1945, 144, 227.

16. Barr, D. P., Dietrick, J., and Whedon, G. D., The effects of bed rest and immobilization on various physiological and chemical functions of normal man. The Conference on Metabolic Aspects of Convalescence, Including Bone and Wound Healing, Conference Reports of the Josiah Macy, Jr. Foundation, Feb., 1945.

17. Cruickshank, E. W. H., and Whitfield, I. C., The behaviour of T. 1824 (Evans blue) in circulating blood and a modified method for the estimation of plasma volume. J. Physiol., 1945, 104, 52.

18. Smith, H. P., The fate of an intravenously injected dye (brilliant vital red) with special reference to its use in blood volume determination. Bull. Johns Hopkins Hosp., 1925, 36, 325.

19. Hahn, P. F., Ross, J. F., Bale, W. F., Balfour, W. M., and Whipple, G. H., Red cell and plasma volumes (circulating and total) as determined by radio iron and by dye. J. Exper. Med., 1942, 75, 221.

20. Lyons, Richard H., Jacobson, Samuel D., and Avery, Noyes L., The change in plasma volume and body weight in normal subjects after a low salt diet, ammonium chloride and mercupurin. Am. J. M. Sc., 1946, 211, 460.

21. Meneely, G. R., and Segaloff, Albert. To be published. 